\title{
Left ventricular outflow tract obstruction due to anomalous mitral valve: successful mitral valve replacement in a four month old infant
}

\author{
P MORAIS, S WESTABY, K A HALLIDIE-SMITH \\ From the Departments of Cardiology and Cardiothoracic Surgery, Royal Postgraduate Medical School \\ (Hammersmith Hospital), London
}

SUMMARY A four month old infant who was investigated for heart failure was found to have mitral incompetence and severe subvalvar aortic stenosis. The left ventricular outflow tract obstruction was found to be due to an anatomically anomalous mitral valve. The obstruction could only be relieved by removal of the mitral valve and its replacement with a St Jude's prosthesis. Two years after operation the child is fit and active. There have been no difficulties with anticoagulant treatment.

In 1957 Ferencz reported an infant with mitral incompetence and left ventricular outflow tract obstruction caused by anatomical malformation of the subvalvar apparatus of the mitral valve. ${ }^{1}$ Since then there have been many excellent necropsy studies, but few clinical reports, of mitral valve abnormalities in which left ventricular outflow tract obstruction was demonstrable in conjunction with mitral stenosis or mitral incompetence. We report a case of severe mitral incompetence and subvalvar aortic stenosis in an infant in whom obstruction of the left ventricular outflow tract was caused by disorganised structure of the subvalvar apparatus of the mitral valve. This obstruction could only be relieved by replacement of the mitral valve. There are few reports of mitral valve replacement in infancy. This child has done well during a two year follow up.

\section{Case report}

The patient was born at 41 weeks' gestation by lower segment caesarean section for fetal distress. He weighed $3.6 \mathrm{~kg}$. Soon after birth a systolic murmur was heard, which was thought to be caused by a small ventricular septal defect. He appeared to thrive and was sent home at 10 days to be followed

Requests for reprints to Dr K A Hallidie-Smith, Department of Clinical Cardiology, Hammersmith Hospital, Du Cane Road, London W120HS. up as an outpatient. When he was four months old he was readmitted to the referring hospital with a 24 hour history of poor feeding. He was severely dyspnoeic and was found to be in heart failure. On transfer to this unit he was extremely tachypnoeic with bulging precordium, subcostal recession, and hepatomegaly. The auscultatory findings were consistent with severe mitral incompetence and a chest radiograph showed pulmonary oedema with enlargement of the left atrium and left ventricle. The electrocardiogram showed left atrial and left ventricular hypertrophy. The cross sectional echocardiogram showed a vigorously contracting left ventricle and dilated left atrium. The possibility of hypertrophic obstructive cardiomyopathy was raised but the hypertrophy appeared to be localised to the mid-cavity. Both leaflets of the mitral valve were visualised and were thought to be normal. The aortic valve was bicuspid. The infant did not improve on nasogastric feeding and a vigorous antifailure regimen, so one week later cardiac catheterisation and angiography were carried out. This confirmed severe mitral regurgitation but in addition a gradient of $90 \mathrm{~mm} \mathrm{Hg}$ was recorded across the left ventricular outflow tract. The aortic valve appeared to be bicuspid and stenotic and angiography of the left ventricle demonstrated gross mitral incompetence into a huge left atrium. The left ventricle was contracting vigorously and the appearance resembled that of hypertrophic obstructive cardiomyopathy. There appeared to be localised nar- 


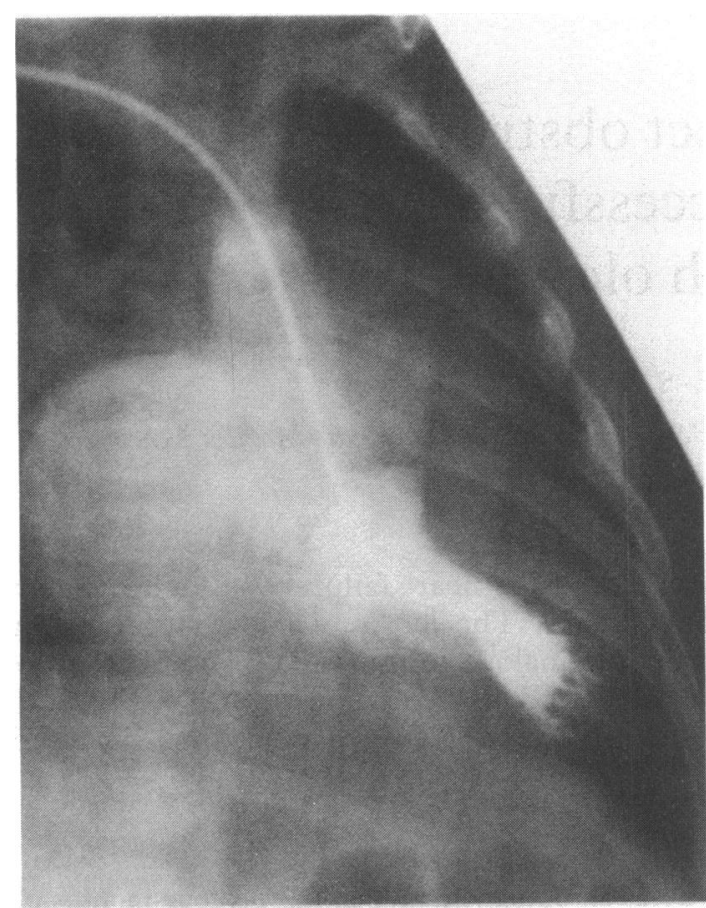

Fig 1 Left ventricular cineangiogram (end systolic frame) showing severe mitral incompetence into a large left atrium. The left ventricle shows a "waisted" appearance in the mid cavity.

rowing in the mid-cavity, however (fig 1). There was some discussion as to whether the obstruction was valvar or subvalvar but because of his clinical condition he was referred for exploration of mitral and aortic valves and the subaortic area.

\section{SURGICAL FINDINGS}

The child was operated on by Mr R N Sapsford with cardiopulmonary bypass and cold potassium cardioplegia for myocardial protection. The aortic valve was bicuspid but not obviously stenosed. The mitral valve, however, was grossly abnormal and unusual in appearance. The annulus was dilated with normal leaflets, but the chordae tendineae were much shortened and inserted directly into sheets of fibrous tissue. There were no recognisable papillary muscles. The tissue supporting the anterior leaflet obstructed the left ventricular outflow tract. There was no generalised endomyocardial fibrosis and the ventricle contracted well. There was a patent foramen ovale and the ventricular septum was intact. In an attempt to avoid mitral valve replacement, a Wooler type mitral annuloplasty was performed and the areas of fusion of the aortic cusps were divided. The major cause of the severe left ventricular outflow tract obstruction was subvalvar and was caused by the abnormal subvalvar apparatus of the mitral valve. Some obstructing tissue was excised from the left ventricular outflow tract but fenestration of the tissue was not feasible. Despite some reduction in the severity of the mitral incompetence, the infant remained in left ventricular failure and it became obvious that he required more adequate relief of the subvalvar aortic obstruction. The abnormal mitral subvalvar apparatus that was causing the obstruction was removed one week later during an elective procedure. On this occasion all the obstructing tissue was excised and the mitral valve and subvalvar apparatus were replaced with a $23 \mathrm{~mm}$ St Jude bileaflet mechanical prosthesis that was easily inserted (fig 2). The outflow tract gradient was reduced to $30 \mathrm{~mm} \mathrm{Hg}$.

The immediate postoperative course was uneventful and signs of heart failure soon disappeared. Good opening and closing sounds of the mitral valve were noted as were signs of mild aortic stenosis. Satisfactory anticoagulant control was achieved with warfarin. Two years later the child is well grown, vigorous, and symptom free. A recent cross sectional echocardiogram shows a normal sized

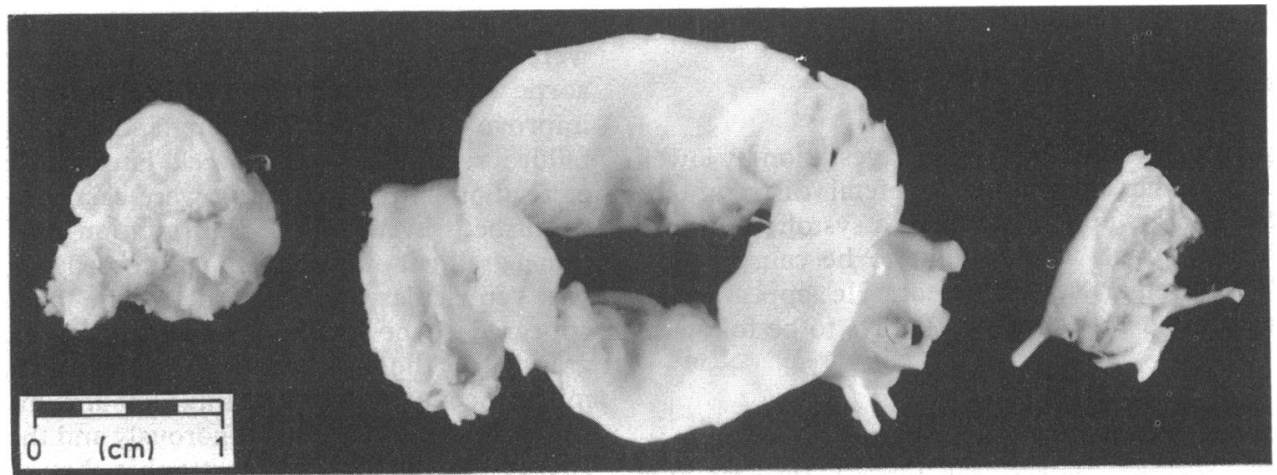

Fig 2 Excised mitral valve showng abnormal subvalvar apparatus and obstructive fibrous tissue. 
left atrium, a mildly hypertrophied left ventricle that is contracting well, a bicuspid aortic valve, and a well seated prosthetic valve. A Doppler study confirmed the absence of paravalvar leak of the prosthetic valve and the presence of mild aortic stenosis and regurgitation. The electrocardiogram shows considerable reduction in left ventricular forces, and the chest radiograph shows a pronounced reduction in heart size. There have been no problems with anticoagulant control; his present regimen is warfarin $2 \mathrm{mg}$ and $2.5 \mathrm{mg}$ on alternate days.

\section{Discussion}

Anatomical abnormalities of the mitral valve and its subvalvar apparatus are well described..$^{2-4}$ Anomalous mitral arcade causing mitral regurgitation because the papillary muscles are inserted directly into the leaflets or by short chordae tendineae was described by Laymon and Edwards. ${ }^{5}$ Subaortic stenosis has been reported in association with the abnormal basal insertion of the anterior mitral leaflet. ${ }^{6}$ In addition, it may occur as a result of accessory valve tissue, restriction of anterior cusp movement by accessory chordae tendineae, or abnormal attachment of valve tissue to the septal wall of the outflow tract. ${ }^{278}$ In our patient the sheets of fibrous subvalvar apparatus obstructed the left ventricular outflow tract and restricted anterior cusp movement in systole, thus causing mitral regurgitation.

Despite the necropsy evidence of subaortic stenosis associated with structural faults of the mitral valve and its apparatus there are few clinical reports of the condition. In this baby the striking clinical features were those of mitral incompetence, and left ventricular outflow tract obstruction was not definitely diagnosed until cardiac catheterisation. In retrospect, there is no doubt that there was a loud systolic murmur radiating to the neck and considerable left ventricular mid-cavity narrowing evident both on the cross sectional echocardiogram and on the left ventricular cineangiocardiogram.

Others have reviewed mitral valve replacement in infants and children..$^{9-11}$ Few successful operations have been reported on infants aged $<6$ months. Selection of the appropriate prosthesis will increase the interval before replacement is needed. ${ }^{12}$ The durability of cardiac bioprostheses is severely restricted by calcification and degeneration in infancy and childhood and for this reason we chose an artificial prosthetic valve for this infant. ${ }^{13-15}$ To postpone the development of stenosis of the prosthetic valve we chose a device with good orifice area to external diameter ratio; a low profile centrally opening prosthesis is probably most suitable for the mitral position. ${ }^{1617}$ We therefore chose the St Jude bi-leaflet prosthesis and implanted a valve with an external diameter of $23 \mathrm{~mm}$ and an orifice area for flow of $2.55 \mathrm{~cm}$. Although the mean native adult mitral valve area is $8.2 \mathrm{~cm}$, we hope that the implanted prosthesis will last for at least 10 years.

\section{References}

1 Ferencz C. Atrio-ventricular defect of membranous septum. Left ventricular right atrial communication with malformed mitral valve simulating aortic stenosis. Report of a case. Bull fohns Hopkins Hosp 1957;100:209-21.

2 Davachi F, Muller JH, Edwards JC. Disease of the mitral valve in infancy. An anatomic analysis of 55 cases. Circulation 1971;43:565-79.

3 Vlad P. Mitral valve anomalies in children. Circulation 1971;43:465-8.

4 Schachner A, Varsani I, Levy MJ. The complex of parachute mitral valve. $f$ Thorac Cardiovasc Surg 1975;70:451-7.

5 Laymon TE, Edwards JE. Anomalous mitral arcade. A type of congenital mitral insufficiency. Circulation 1967;35:389-95.

6 Björk VD, Halquist G, Lodon H. Subaortic stenosis produced by an abnormally placed anterior mitral leaflet. F Thorac Cardiovasc Surg 1961;41:659-62.

7 Sellers RD, Lillehei CW, Edwards JE. Subaortic stenosis caused by anomalies of the atrio-ventricular valves. F Thorac Cardiovasc Surg 1964;48:289-302.

8 Edwards JE. Pathology of left ventricular outflow tract obstruction. Circulation 1965;31:586-97.

9 Nudelman I, Schachner A, Levy MJ. Repeated mitral valve replacement in the growing child with congenital mitral valve disease. $\mathcal{f}$ Thorac Cardiovasc Surg 1980;79:765-9.

10 Williams WG, Pollock JC, Geiss DM, Trusler GA, Fowler RS. Experience with aortic and mitral valve replacement in children. $\mathcal{F}$ Thorac Cardiovasc Surg 1981;81:326-33.

11 Friedman S, Edmunds LH, Cuaso CC. Mitral valve replacement in young children. Long term influence of somatic growth on prosthetic valve adequacy. Circulation 1977;56(suppl 2):117-21.

12 Gardner TJ, Ronald JMA, Weill CA, Donahuo JS. Valve replacement in children: a 15 year prospective. f Thorac Cardiovasc Surg 1982;83:178-85.

13 Thardroyen FT, Whitton IN, Pirie D, Rogers MA, Mitha AS. Severe calcification of gluteraldehyde preserved porcine xerografts in children. Am $\mathcal{F}$ Cardiol 1980;45:690-6.

14 Dunn JM. Porcine valve durability in children. Ann Thorac Surg 1981;32:357-68.

15 Silver MM, Pollock S, Silver MD, Williams WG, Trusler GA. Calcification of porcine xenograft valve in children. Am $\mathcal{F}$ Cardiol 1980;45:685-9.

16 Human DG, Joffe HS, Fraser CB, Barnard CN. Mitral valve replacement in children. $\mathcal{F}$ Thorac Cardiovasc Surg 1982;83:873-7.

17 Westaby S, Karp RB, Blackstone EH, Bishop S. Adult human valve sizes and their surgical significance. $\mathrm{Am}$ f Cardiol 1983;53:552-7. 